\title{
HISTOLOGICAL STUDIES ON SOME IMMUNE ORGANS OF OREOCHROMIS NILOTICUS (TILAPIA NILOTICA)
}

\author{
Mamdouh A. EL-Shammaa, Hany A. El-Habback, Gehad, A. El-Bargeesy \\ and Shymaa H. Hussein
}

Department of cytology and histology, Faculty of vet. Med. Cairo University.

\begin{abstract}
The thymus of Tilapia nilotica (Oreochromis niloticus) was covered by thin capsule with short trabeculae. The parenchyma was differentiated into cortex and medulla; the cortex consisted of dense population of lymphoid cells and few epithelial reticular cells, while the medulla consisted of few lymphoid cells and abundant epithelial reticular cells. Thymic corpuscle-like structures also detected in the medulla. The parenchyma also contained pigmented macrophages and mast cells. The kidney of Tilapia nilotica (Oreochromis niloticus) was differentiated into two parts; head and trunk kidneys. Head kidney could not differentiated into cortex and medulla. The subcapsular region contained haemopoietic tissue. The haemopoietic elements were represented by different types of cells. Non encapsulated melano-macrophage centres were found either sporadic or as clusters. Corpuscle of Stannius was seen embedded in the parenchyma. The trunk kidney was formed of nephrons and interstitial tissue which was represented by haemopoietic tissue, lymphoid tissue and melano-macrophages. The spleen was surrounded by thin capsule. The spleen was composed of red, ill developed white pulp and accumulation of melano-macrophages. The subcapsular region occupied mostly by the red pulp. Also the spleen contained haemopoietic tissue. Some exocrine pancreatic acini were noticed at subcapsular region. Melano-macrophage centres were found around the vascular channels and embedded in the parenchyma.
\end{abstract}




\section{INTRODUCTION}

The available literatures agreed on the organs implicated in the immune system of fish and its formation to be the thymus, kidney and spleen. In addition, diffuse haemopoiesis occurring out side these definite organs was mentioned by (El-Shammaa,1987). Significant differences are apparent between the immune system of fish and mammals including the absence of bone marrow and lymph nodes in fish. The gut associated lymphatic tissue (GALT) is underdeveloped in teleosts (Takashima and Hibiya, 1995). In our studies, the Nile Tilapia (Oreochromis niloticus), is one of the best known commercial species. Moreover it is common in many areas and it is relatively easy to rear under controlled conditions in aquaria. The aim of the present study is to establish the structural organization of the immune system of Oreochromis niloticus fish represented by thymus, kidney and spleen.These data may be considered the key issue for determining the state of immuno-competence that allow fish to respond to pathogens and reach protection by vaccination. Moreover, the three organs are considered also as a monitor which reflect the quality of the aquaculture.

\section{MATERIALS AND METHODS}

The material used in this study was 50 of Tilapia nilotica fish (Oreochromis niloticus) obtained from Giza and El-Fayoum. Sex was not considered and the fish ranged between 50- $70 \mathrm{gm}$ in weight for thymus and 250-350 gms for kidney and spleen. The thymus,kidney and spleen were collected then washed gently in $0.9 \%$ saline solution and were immediately immersed in different fixatives (10\% neutral buffered formalin, Bouins, Sussa fluid and Zenker formol). The samples were processed and embedded in paraffin wax, then stained with $H \& E$, Crossmon's trichrome stain, Gomori's reticulin, PAS and AB $(\mathrm{pH} 1.0$ 
and 2.5) methods. Masson's fontana(for melanin), Longziehl Neelsen(for lipofuscin) and Toludine blue stains were also used. The fixatives and staining methods were used as outlined by Crossmon (1937); Pearse (1972); Cook (1974); Drury and Wallington (1980); Bancroft and Stevens (1982) and Freida and Carson(1990).

\section{RESULTS}

\section{Thymus:}

The present investigation revealed that the thymus of Tilapia nilotica (Oreochromis niloticus) situated subcutaneously in the dorsal commissure of the operculum and dorsolateral to the pharynx. The thymus was bilobed organ and could be seen in the same section separated from the head kidney by cell "bridges" (Fig.1). The thymus was surrounded by a thin connective tissue capsule consisted of collagen fibers, smooth muscles and reticular fibers. The capsular cells were epithelial and continuous immediately by a layer of blast cells of the cortex (Fig.2). This capsule slightly protruded into the thymic parenchyma by short connective tissue trabeculae ( Fig.3).

The parenchyma of the thymus composed of an outer dense cortical region and a light inner medulla (Fig.3). The cortex was formed of few epithelial reticular cells, dense population of lymphoid cells. The thymocytes were different in size; some of them were large with small centrally situated nucleus and pale peripheral cytoplasm while others were small in size occupied mostly by a deeply stained nucleus, quite similar to the lymphocytes, some of them showing mitotic figures (Fig.4). The epithelial reticular cells were large, stellate with lightly stained cytoplasm and had large vesicular nuclei with peripheral dense chromatins. The medulla of the thymus consisted of less dense population of the lymphoid cells but the epithelial reticular cells were more prominent and numerous (Fig.5). 
In addition, there were other types of epithelial cells. The first one was very large in size, rounded or ovoided in shape with lightly acidophilic cytoplasm and large spherical vesicular nucleus with clear nucleolus (Figs. 6\&7\&8). The second one were also large in size, irregular in shape and contained many engulfed cells (Fig.9). The third one of epithelial cells were detected sporadic in the vicinity of the medulla near the first type of cells and inbetween the thymocytes. These cells were large irregular; their nuclei were rounded to elongated and shifted toward the periphery by the cytoplasm (Fig.10). They were engorged with secretory granules, that occupied most of the cytoplasm and gave a positive reaction toward both PAS (Fig.8) and Alcian blue (Fig.11). Thymic corpuscle-like structure was composed of central degenerated epithelial reticular cells which were surrounded by concentrically arranged crescentic epithelial reticular cells (Fig.12) . Some macrophages contained melanin and haemosidrin granules in their cytoplasm and appeared as melanin containing cells, but not forming centres. There were aggregations of erythropoietic foci containing developing and mature erythrocytes dispersed in the meshes of the epithelial reticular cells.

Many vascular channels appeared lined by endothelial cells and were surrounded by reticular cells (Fig.13). Also there were blood capillaries in the parenchyma of the thymus (Figs.5\&11). Mast cells were observed contained metachromatic granules that partially or completely obscure the nucleus and were located adjacent to the blood vessels (Figs.7\&8). Some parts of the parenchyma showed some apoptotic thymocytes with pyknotic nuclei which were more apparent in the cortex than in the medulla (Fig.14). Prominent irregular vacuoles of different sizes were observed (Fig.15). 


\section{Head Kidney:}

The head kidney covered the entire pharynx and consisted of two lobes joined posterio-medially. These bilateral glandular tissues masses of the head kidney were separated dorso-medially by the descending epipharyngeal muscles. Each lobe was divided into lobules by connective tissue that showed nerve bundles (Fig.16). Head kidney parenchyma of Tilapia nilotica was composed of haemopoietic tissue, lymphoid tissue and pigment granules (Fig.17). The head kidney was surrounded by a thin capsule consisted of collagen fibers, smooth muscles and reticular fibers. The caudal portion of the head kidney of each lobe was ventrally enclosed by a mesothelial layer.

It was difficult to distinguish the cortex from the medulla where the cellular elements of the head kidney were evenly distributed. The more characteristic feature was the apparent presence of haemopoietic tissue in the subcapsular region. The haemopoietic tissue, which was consisted of developing erythrocytes and granulopoietic elements, was also distributed around the conventional veins of the head kidney. Some veins of these vessels were appeared surrounded by densely packed lymphoid cells (lymphoid aggregates). The a forementioned picture gave the head kidney the appearance of the red and white pulp of the mammalian spleen. Some blood cells were detected either in the lumen of some blood vessels or around them (Fig.18).

Regarding the stromal cells of the head kidney, there were two types; the first type of the stromal cells appeared irregular with some cytoplasmic processes running through the haemopoietic parenchyma and the lymphoid tissue (Fig.19); the second type was flat with very thin cell processes, and had flattened nucleus. These cells were found surrounding the blood vessels and the melano-macrophage centres(Figs. 20\& 21). 
Hormonal cells of the suprarenal tissue (adrenal cortex and medulla) which called subendothelial endocrine cells. They were closely associated with the posterior cardinal veins and their tributaries in the head kidney and were separated from the blood vessels by a thin connective tissue. These cells were divided into two types of cells; interrenal cells and chromaffin cells. Both cells were polygonal; interrenal cells had round nuclei, with little chromatin and distinct nucleoli, the cytoplasm was homogenous dark acidophilic. The large pale chromaffin cells had oval or irregular nuclei and contain little chromatin with pale cytoplasm (Fig.21). Both cells showed negative reaction to PAS and Alcian blue techniques. Macrophages were seen as large cells with kidney-shaped and eccentric nuclei.

Melano-macrophage centres (MMCs) were rounded, oval or irregular in outline. The most occupied cell population had eccentrically placed nuclei, their cytoplasm appeared vacuolated and contained yellow brick phagocytosed granules. MMCs were surrounded by lymphocytes, reticular cells, red blood cells and granulocytes. There was minute reticular fibers without forming capsule delimiting the MMCs (Fig.22). Melano-macrophage centres took light magenta color with LongziehlNeelsen (Fig.23), purple color with PAS technique and dark brown to black with Masson's fontana stain. However, they reacted negatively with $\mathrm{AB}$ stain.

Corpuscles of Stannius appeared as one type of cell arranged in radical fashion around some veins or embedded in the parenchyma either as columns or in the form of clumps. Between these cells, there were blood sinusoids lined with large sized endothelial cells with darkly stained nuclei. The cells of corpuscles were large in size, polyhedral in shape and contained granular acidophilic cytoplasm with large, spherical and lightly stained nuclei with prominent nucleoli (Figs.16\&24). 
Head kidney revealed isolated groups of cells in the parenchyma. These cells were oval to elongated shaped with spherical or irregular basally situated nucleus. These isolated groups of cells were surrounded by reticular cells (Fig.25). Also these cells might be found around the blood vessels (Fig.20). Mast cells were observed containing metachromatic granules that obscured the nucleus and were located adjacent to the vascular channels intermingled with the corpuscle of Stannius.

\section{Trunk kidney:}

Trunk kidney was located beanth the vertebral column. There was interstitial tissue between the nephrons represented by haemopoietic tissue, lymphoid tissue and melano-macrophages(Fig.26). These melanomacrophages appeared as free macrophages containing pigments or clusters supported by some reticular fibers without forming capsule. Oval to elongate cells with an irregular, darkly stained and basally located nuclei were observed in the renal tubules of the trunk kidney.

\section{Spleen:}

This organ was covered by thin fibrous connective tissue capsule contained collagen fibers, smooth muscles and fibroblasts. It was covered with single layer of mesothelial cells. The capsule gave connective tissue trabeculae that penetrate the interior of the spleen. These trabeculae contained collagen and smooth muscle fibres, blood vessels and were surrounded by some melano-macrophages (Fig.27). Some exocrine pancreatic acini were noticed in the subcapsular region (Fig.28) and followed the course of major blood vessels to the organ.

The parenchyma of the spleen could be divided into a red and ill developed white pulp. The red pulp might occupy the majority of the organ and consisted of lymphoid cords with sinusoids inbetween. Both 
cords and sinusoids were supported by reticular cells (Fig. 29). The subcapsular region mainly occupied by the red pulp. The white pulp was often poorly developed

but might be divided into two compartments; the melanomacrophage centres ( MMCs ) and lymphoid tissue. The lymphoid tissue was represented by large aggregation of lymphocytes, macrophages and plasma cells and was supported by reticular cells. All of these cellular components were observed around the central arteries and peripheral ellipsoids resembling white pulp of mammalian spleen. The peripheral ellipsoids, which were the narrow terminal branch of the arterioles, were also surrounded by melano-macrophage centres (Figs.30\&31). Moreover there was haemopoeitic tissue distributed among the splenic parenchyma.

The melano-macrophages appeared as free cells, clusters or partially encapsulated. The free melano-macrophages were randomly distributed and observed as isolated cells. The melano-macrophages had rounded, oval or irregular outline and frequently occurred in close association with the vasculature of the organ. They consisted of few or large clumps of cells which were sometimes partially encapsulated. The capsule appeared thin and consisted of a single layer of flat cells with elongated central nuclei (Fig.31).

Moreover they were surrounded by granulocytes and lymphoid cells. Both free and the clusters of melano-macrophages contained a granular or heterogeneous pigmented materials ranging from yellow to dark brown . Melano-macrophage centres took purple color with PAS technique, light magenta color with Longziehl-Neelsen stain. In addition it gave dark brown to black with Masson's fontana stain(Fig.32) and reacted negatively with $\mathrm{AB}$ stain. 


\section{DISCUSSION}

\section{Thymus:}

The thymus had thin capsule consisted of collagen fibers, smooth muscles and reticular fibers. The capsular cells were epithelial and continuous immediately by a layer of blast cells of the cortex.The capsule slightly invaginated into the stroma producing trabeculae. This was described also by Sailendri and Muthukkaruppan (1975); inTilapia mossambica, Sameerah (1991); in Red tilapia, Zapata, Torroba, Sacedon, Varas and Vicente (1996); in elasmobranchs and Bowden, cook and Rombout (2005); in Atlantic halibut.

The thymus consisted of an outer dense cortex and an inner light medulla. This was the same as reported by Grizzle and Rogers (1979); in channel cat fish, Sameerah (1991); in Red tilapia, Diab, Marei, and Smith (1995); in Nile tilapia and Fournier-Betz, Quentel, Lamour and Le Ven (2000); in rainbow trout. Neither inner nor outer zone were reported by Ellis (1977), in Salmo salar L., Manning (1981); in dogfish, El-Shammaa (1987); in carp and Liu,Zhang,Jiang,Yang,Lian and Yang (2004); in both juvenile and adult flounder. On contrary, Rizkalla (1969); in clarius lazera noticed three distinct zones.

The cortex was formed of few epithelial reticular cells and dense population of lymphoid cells, while the medulla of the thymus consisted of less dense population of the lymphoid cells but the epithelial reticular cells were more prominent, numerous and formed a supporting meshwork. These results were similar to that observed by Rizkalla (1969); in clarius lazera, Diab et al. (1995); in Nile tilapia and Takashima and Hibiya (1995); in teleosts. In addition, El-Shammaa (1987); in carp, Sameerah (1991); in Red tilapia and Bowden et al. (2005) in Atlantic halibut mentioned that the cortex contains 
macrophages. The functional inter-relationship between the thymocytes and the epithelial reticular cells was not resolved and some authors proposed that epithelial reticular cells produce factors important for thymocytes maturation and the acquisition of specific immune characteristics of thymocytes in teleosts. A wide range of lymphoepithelial interactions occurs throughout thymocytes differentiation (Press and Evensen,1999).

Thymus was important organ in the endocrine, haemopoietic and immune systems of fish (Chilmonczyk,1984; in rainbow trout and LópezRuiz, Esteban, and Meseguer,1992; in seabream). However, Takashima and Hibiya (1995); in teleosts considered that the thymus was responsible for the final maturation of T-cells as well as it facilitates and regulates the interaction of lymphoid and non-lymphoid cells (Boehm, Bleul and Schorpp, 2003); in zebra fish.

This study revealed other types of epithelial cells. The first type of cells was large in size, rounded or ovoided in shape. These cells were observed in elasmobranchs (Zapata et al. 1996) and in flounder(Liu et al. 2004) and were named myoid cells which occupied mainly the thymic medulla. The second one was large in size, irregular in shape and contained many engulfed cells. These cells were named nurse cells by Bowden et al. (2005) in teleosts. The authors explained that thymocytes could be engulfed by nurse cells and described it as keratin-containing epithelial cells. But Ohl, Bernhardt, Pabst, and Forster (2003) mentioned that non-functional apoptotic thymocytes were engulfed by macrophages. The third one was present sporadic they were not commonly mentioned by authors, although they were detected in the inner zone of rainbow trout thymus (Castillo, Razquin, Lopez-fierro, Alvarez, Zapata and Villena, 1990). 
Corresponding to Rizkalla (1969); in clarias lazera, El-Shammaa (1987); in carp, Romano, Fanelli, Del Papa, Scapigliati and Mastrolia (1999); in seabream, Roberts (2001); in teleosts and Fishelson (2006); in cichild fishes, the medulla of Tilapia nilotica contained thymic corpuscle-like structures which comparable to true Hassall's corpuscle. Results of Alvarez,Flano, Villena,Zapata and Razquin (1994); in the rainbow trout, Bagchi and Pal (2004); in Cirrhinus mrigala and our study revealed an aggregation of erythropoietic foci containing developing and mature erythrocytes dispersed in the meshes of the epithelial reticular cells. Schneider (1983) reported that the thymus was important haemopoietic organ in fish. Our work illustrated that the vascular channels were lined by endothelial cells and were surrounded by reticular cells; this figure might represent blood thymus barrier (Diab et al., 1995; in Nile tilapia and Lin,Lin and Yang, 2005; in Epinephelus malabaricus). Press and Evensen (1999), in teleosts reported that this barrier might have a crucial immunological role in preventing direct exposure of thymocytes to potential pathogens and toxic substances in the circulating blood and body fluids in teleosts.

Mast cells were recorded which lied adjacent to the blood vessels; In this respect; Xu-Leren,Yang-Xiaozhen,Gao-Denghui and Jiang-Ping (2003) detected mast cells near the thymic blood vessels in grass fish and cat fish. Mast cell may secrete histamine as that recorded by Ellis, Munro and Roberts 1976; in plaice. The thymic parenchyma showed some apoptotic thymocytes as well as prominent irregular vacuoles of different sizes. These results were similar to that detected in carp; ElShammaa(1987) and in sea bass; Abelli, Baldassini, Meschini, and Mastrolia (1998), who contributed that to the beginning of the thymus involution. 


\section{Head kidney:}

Head kidney of Tilapia nilotica was surrounded by a thin capsule consisted of collagen fibers, smooth muscles and reticular fibers. Caudal portion of the head kidney of each lobe was ventrally enclosed by a mesothelial layer, which was similar to what detected by Beitch (1962); in striped bass. In agreement with Fishelson (1996) in cichlid fish, it was difficult to distinguish the cortex from the medulla, where the cellular elements of the head kidney were evenly distributed. The more characteristic feature was the apparent presence of haemopoietic tissue in the subcapsular region. In contrary with Sailendri and Muthukkarppan (1975); in Tilapia mossambica, Ellis et al. (1976); in plaice and Sameerah (1991); in Red tilapia, who observed cortex and medulla which contain haemopoietic tissue and lymphoid aggregates respectively.

Two types of veins were distinguished in the head kidney; the conventional vein and the portal vein. The later appeared surrounded by lymphoid aggregation and drained from the caudal vein. The arrangement of blood vessels in head kidney of Tilapia nilotica was similar to that described in head kidney of carp; Imagawa, Hashimoto, kon and Sugimura (1990) and of seabream; Abd-Rabou (2002). In teleosts head and trunk kidney were the major compensatory sites of trapping and processing injected materials(Lamers \& De Haas ,1985). In carp; Imagawa et al. (1990) claimed that the arrangement of blood vessels in the head kidney might be favorable for trapping foreign materials.

Head kidney of Tilapia nilotica appeared to be consisted of a red and a white pulp which agreed with Sailendri and Muthukkaruppan (1975); in Tilapia mossambica, Imagawa et al. (1990); in carp and AbdRabou (2002); in Gilthead seabream. The later observation was

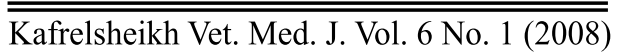


explained by Ellis (1977); in salmon, Lòpez-Ruis et al (1992); in seabream,Fishelson,1996; in cichildae, Abd-Rabou (2002); in seabream as the parenchyma of the head kidney was formed of pale areas of granulopoeisis and darker areas of lymphopoiesis surrounded by an area of erythropiesis without forming definite zones.

The stromal cells were of two types. The first one was similar to that detected in Gilthead seabream by Abd-Rabou (2002), who claimed that they were similar in morphological feature to macrophage-type reticular cell. The second stromal cell appeared to be similar to that detected by Meseguer,Lopez-Ruis and Gracia-Ayala,(1995); in seabream and Abd-Rabou, (2002); in Gilthead seabream. They mentioned that these cells were similar in morphological feature to fibroblast-like cells and act as physical support to the haemopoietic cells and could also influence their differentiation.

Similar to Roberts (1975); in teleost fish, Groman (1982); in striped bass, Herraez and Zapata (1991); in goldfish, Abd-Rabou (2002); in seabream and Lin et al. (2005); in Epinephelus malabaricus who claimed that melano-macrophage centres were round, oval or irregular in outline, the most occupied cell population had cytoplasm contained yellow phagocytosed granules. Agius (1979); in fish and Macchi, Romano and Christiansen (1992); in white mouth reported that melano-macrophage centres beside their immunological function could act as metabolic dumps for removal of old damaged red bloodcells. They participated in rapid and active clearance of pathogenic organism from circulation, and in scavenging of cellular degradation products. The role of melano-macrophage centres in the recognition of antigen by the immune system was first suggested by Herraez and Zapata (1991); in gold fish. 
Hormonal cells of the suprarenal tissue (adrenal cortex and medulla) of Tilapia nilotica which called subendothelial endocrine cells. These cells were of two types; interrenal cells and chromaffin cells. This result was similar to that detected by Groman (1982); in striped bass, ElShammaa(1987); in carp and Abd-Rabou(2002); in seabream. On contrary Grizzle and Rogers (1979); in channel catfish and Takashima and Hibiya(1995); in teleosts, who demonstrated interrenal tissue in the head kidney and considered it as homologous to mammalian adrenal cortex. They noticed also the presence of chromaffin cells inbetween haemopoietic tissue and referred to it as homologous to mammalian adrenal medulla. Our results revealed that the interrenal and chromaffin cells were absent in the parenchyma of the head kidney away from the blood vessels these results were similar to that observed by $\boldsymbol{A b \boldsymbol { d }} \boldsymbol{R} \boldsymbol{a b o u}$ (2002) in sea bream.

The corpuscle of Stannius was formed of cords and clumps of cells of one type arranged in radical fashion around the vein. The same was mentioned by Carpenter and Hely (1974); in salmon and Abd-Rabou (2002); in seabream. Urasa and Wendelaar-Bonga (1985); in cichlid teleost and Takashima and Hibiya (1995); in teleosts established that corpuscles of Stannius play a role, in conjunction with pituitary gland, to produce a hypocalcemic hormone to maintain a relatively constant level of calcium. Also Wendelaar-Bonga and Greven(1975); in euryhaline teleosts postulated that the corpuscle of Stannius produce a hypocalcemic hormone(named occasionally stannocalcin). They proposed that it was associated with steroidogenic activity.

Head kidney revealed isolated groups of cells in the parenchyma. These cells were similar to that detected by Dezfuli, Simoni, Rossi, and Manera, (2000); in Phoxinus phoxinus; and Mazon,Huising,TaverneThiele,Bastiaans and Verburg-van Kamenade(2007); in carp. Reite 
(2005); in teleostean fish suggested that the rodlet cells themself may represent a type of eosinophilic granulocytes. The high number of young rodlet cells in the kidney could suggest that these cells proliferate in the kidney and then migrate to the gills (Mazon et al. 2007); in teleosts.

Our investigation revealed continuation of the head kidney with the trunk kidney rostrally so that the caudal portion of the head kidney contained renal tubules and there was no actual separation between the two parts; this result agreed with (Groman, 1982; in striped bass and Grove,Johansen, Reitan and Press 2006; in Atlantic halibut ).

\section{Trunk Kidney:}

The trunk kidney had the distribution of nephrons in relation to haemopoietic tissue. the interstitial tissue of trunk kidney was composed of haemopoietic cells and melano-macrophage centres. Haemopoiesis was also working in trunk kidney. Our previous results were similar to that described by Bielek (1981); in teleost species,El-Shammaa (1987); in carp, Sameerah (1991); in Red tilapia, Roberts (2001); in teleosts and Abd-Rabou (2002); in seabream. Melano-macrophage cells in the haemopoietic tissue of trunk kidney usually increase in frequency in association with tissue catabolism such as the degeneration of haemopoietic tissue (Agius and Roberts, 2003). Rodlet cells were observed in renal tubules of the trunk kidney; this result was recorded by Dezfuli et al. (2000); in Phoxinus phoxinus, Manera \& Dezfuli (2004); in teleosts and Mazon et al. (2007); in teleosts. These cells could play a role in defense mechanism through proteolytic activity.

\section{Spleen:}

The present investigation revealed that the spleen of Tilapia nilotica (Oreochromis niloticus) was covered by thin fibrous connective tissue capsule (with c.t. trabeculae) which contained collagen fibers, smooth 
muscles and fibroblasts. The capsule was covered with single layer of mesothelial cells. These results were similar to that detected by $\boldsymbol{E l}$ Shammaa (1987); in carp, Takashima and Hibiya (1995); in teleosts and Marei (2003); in Nile tilapia. While Yoffey (1929); in dog fish mentioned that the splenic capsule devoid of smooth muscles. The author added that exocrine pancreatic acini were located in subcapsular region, this was the same in our work; pancreatic acini were noticed also following the course of major blood vessels and nerves.

The parenchyma of the spleen could be divided into a red and ill developed white pulp. The same results were noticed by Sameerah (1991); in Red tilapia and Marei (2003); in Nile tilapia. But ElShammaa (1987); in carp and Liu et al( 2004); in flounder, mentioned that there was no distinct red and white pulp in the spleen. Our investigation revealed that the red pulp might occupy the majority of the organ; mainly present in the subcapsular region and were supported by reticular cells. These findings came in agreement with El-Shammaa (1987); in carp and Sameerah (1991) in Red tilapia. These capsular sinuses act as reservoir for the red blood cells and the plasma fluid (Sailendri and Muthukkaruppan, 1975; in Tilapia mossambica). The reticular cells made destruction to the old red blood cells (Agius, 1979). Moreover Press and Evensen (1999); in teleosts, mentioned that the reticular cells hold diverse cell populations including macrophages and lymphocytes.

In agreement with Ellis (1976); in plaice and Marei (2003); in Nile tilapia, white pulp in the spleen might be divided into two compartments; the lymphoid tissue and melano-macrophage centres (MMCs). The lymphoid tissue was seen surrounded the central arteries and peripheral ellipsoids constituted what was called splenic white pulp, this result agreed with Zapata (1980) and Lin et al. (2005); in Epinephelus 
malabaricus. The lymphoid tissue was represented by large aggregations of lymphocytes and macrophages. These macrophages might have a general role in erythrocytes destruction. Also lymphoid tissue contained plasma cells; the same was reported by Zapata (1980) and Zapata et al. (1996) ; in elasmobranch. The presence of plasma cells suggested by Petrie-Hanson and Ainsworth (2000); in channel cat fish and Marei (2003); in Nile tilapia, as the spleen was the site of plasma cells development and consequently antibodies production.

The spleen contained haemopoietic tissue, this agreed with Anderson and Mitchum,(1974); in Trout and Sameerah (1991); in Red tilapia. Spleen had crucial roles in immunological defense mechanisms and haemopoiesis of fish (Secombes,Manning and Ellis, 1982; in carp and Alvarez, Razquin, Villena, and Zapata 1998; in Wild brown Trout). But Grizzle and Rogers (1979) in channel catfish indicated that the spleen was less important in haemopoiesis.

The melano-macrophages in the spleen appeared as free cells or clusters; they frequently occurred in close association with the vasculature of the organ. This result was agreed with Agius (1980); in teleosts, Press, Dannevig, and Landsverk (1994); in Atlantic salmon, Marei (2003); in Nile tilapia and Lin et al. (2005); in Epinephelus malabaricus. In agreement with Press et al. (1994); in Atlantic salmon, melano-macrophage centres in the spleen of Tilapia nilotica were surrounded by granulocytes and lymphoid cells. The circulating small lymphocytes migrate to the melano-macrophage centres and suggested that they were the sites where trapped antigen might interact with the immune system (Lamers and De Haas 1985; in carp). In the present work, melano-macrophage centres took dark brown to black with Masson's fontana stain; these indicated (according to Meseguer et al. 1995; in Gilthead seabream) the presence of melanin. Positive 
Longziehl-Neelsen, in our investigation, gave an indication to presence of lipofuscin. Lipofuscin had been called wear and tear pigment that accumulating with age and tissue destruction. It was the most widespread pigment in the melano-macrophage centres of many fish species (Agius, 1979).

The peripheral ellipsoids in the spleen of Tilapia nilotica, which were the narrow terminal branch of the arterioles, were also surrounded by melano-macrophage centres; this result was agreed with Espense, Press, Dannevig, and Landsverk (1995); in rainbow trout. The ellipsoids in the spleen of teleosts had repeatedly been demonstrated to trap different particulate and non particulate substances such as old cells, pathogens and / or protein aggregates replete macrophages then migrate from the ellipsoids to MMCs (Lamers \& De Haas ,1985; in cyprinid and Dalmo \& Hogwald, 1996; in Atlantic salmon).

\section{LIST OF FIGURES}

Fig.(1): Cross section in Tilapia nilotica showing that the thymus (T) was connected to the head kidney $(\mathrm{K})$ by cell "bridges" (arrow).(H\&E, X200).

Fig. (2): High magnification of fig. (1) showing the epithelial cell (arrow), fibrobast (f), smooth muscle fiber ( $\mathrm{Sm}$ ) of the capsule that covered a layer of blast cells (B) of the cortex. ( H\&E, X1025).

Fig. (3): A section in the thymus showing connective tissue trabecula (T), dense outer cortical region (C) and light inner medulla (M). (H\&E, X200).

Fig. (4): A section in the cortex of the thymus showing few epithelial reticular cells (R) and dense population of lymphoid cells. Notice the mitotic figures (arrows). (H\&E, X1025). 
Fig. (5): A section in the thymic medulla showing more epithelial reticular cells $(\mathrm{R})$, less dense population of the lymphoid cells and blood capillary (C). (H\&E, X1025).

Fig. (6): A section in the thymic medulla showing the first type of cells (arrow) which were large in size, with lightly acidophilic cytoplasm and contained large spherical vesicular nucleus with clear nucleolus. (PAS, X1025).

Fig. (7): A section in the thymus showing mast cells contain metachromatic granules (m). Notice first type of epithelial cells (arrow). (Toludine blue, X1025).

Fig. (8): A section in the thymic medulla showing mast cell (m), first type of epithelial cells (arrow A) and PAS positive third type of epithelial cells (arrow B). (PAS, X1025).

Fig. (9): A section in the thymic cortex showing the second type of cells (arrow) which were large in size, irregular in shape and contained many engulfed cells. (H\&E, X1025).

Fig. (10): A section in the thymic medulla showing the third cell type (arrow) which was large, irregular with elongated and peripherally situated nucleus. (H\&E, X1025).

Fig. (11): A section in the thymic medulla showing the third cell type engorged with secretory granules and gave a positive reaction toward Alcian blue (arrow). Notice the reticular cells (R) and the capillary (C). (Alcian blue 2.5, X1025).

Fig. (12): A section in the thymic medulla showing thymic corpuscle-like structure (arrow) composed of central concentrically arranged epithelial reticular cells with degenerated centre. Notice the reticular cells(R). (H\&E, X1025).

Fig. (13): A section in the thymus showing a vascular channel appeared lined by endothelial cells (arrow) and surrounded by reticular cells (R). (H\&E, X1025). 
Fig. (14): A section in the thymic cortex showing some apoptotic thymocytes with pyknotic nuclei (arrows). (H\&E, X1025).

Fig. (15): A section in the thymus showing prominent irregular vacuoles of different sizes (arrows). (Alcian blue 2.5, X1025).

Fig. (16): A section in the head kidney showing its lobulation (arrow) inbetween them connective tissue and nerve bundles $(\mathrm{N})$. Notice corpuscle of Stannius (S). (H\&E. X50).

Fig. (17): A section in the head kidney showing parenchyma which composed of haemopoietic tissue $(\mathrm{H})$, lymphoid tissue (L) and pigment granules (M). (H\&E, X410).

Fig. (18): A section in the head kidney showing aggregation of the lymphoid tissue around the portal vein $(\mathrm{P})$ and haemopoietic tissue around the conventional vein (C). (H\&E, X200).

Fig. (19): A section in the head kidney showing first type of stromal cells (S1) which support haemopoietic tissue and lymphoid tissue. (H\&E, X1025).

Fig. (20): A section in the head kidney showing second type of stromal cells (S2) around the blood vessels (V). Notice oval to elongated cells with an irregular basally located nuclei (arrow).(H\&E,X1025).

Fig. (21): A section in the head kidney showing subendothelial chromaffin cells (C) and interrenal cells (I) and second type of stromal cells (S2) that appeared around the blood vessel(V). (H\&E, X410).

Fig. (22): A section in the head kidney showing melano-macrophage centre (M) not surrounded by reticular fibers capsule. (Gomori, X410).

Fig. (23): A section in the head kidney showing melano-macrophage centre (M) took light magenta color with Longziehl-Neelsen stain. (Longziehl-Neelsen, X410). 
Fig. (24): A section in the head kidney showing the cells of corpuscles of Stannius arranged in radical fashion around the vein (V) with blood sinusoids (S) inbetween. (H\&E, X200).

Fig. (25): High magnification showing oval to elongated shaped cells (arrow) with spherical or basally located nuclei. These cells were surrounded by reticular cells (R). (H\&E, X1025).

Fig. (26): A section in the trunk kidney showing interstitial tissue (arrow) consisted of haemopoietic tissue, lymphoid tissue and melanomacrophages. (H\&E, X410).

Fig. (27): A section in the spleen showing trabeculae (T) carried blood vessels (arrow). Notice some melano-macrophages (M) adjacent to the trabeculae. (Crossmon, X410).

Fig. (28): A section in the spleen showing some exocrine pancreatic acini (arrow) in the subcapsular region. (H\&E, X410).

Fig. (29): A section in the spleen showing the red pulp consisted of lymphoid cords with sinusoids (S) inbetween. Both cords and sinusoids were supported by reticular cell (arrows). (H\&E, X1025).

Fig. (30): A section in the spleen showing lymphoid tissue around the peripheral ellipsoids (arrow). Notice melano-macrophages (M). (H\&E, X1025).

Fig. (31): A section in the spleen showing encapsulated melano-macrophage centre (M) associated with the vascular channels (V) and surrounded the ellipsoid (e). (H\&E, X410).

Fig.(32): A section in the spleen showing melano-macrophage centre (M) took dark brown to black. (Masson's Fontana stain X410). 
Mamdouh A. EL-Shammaa et al.,

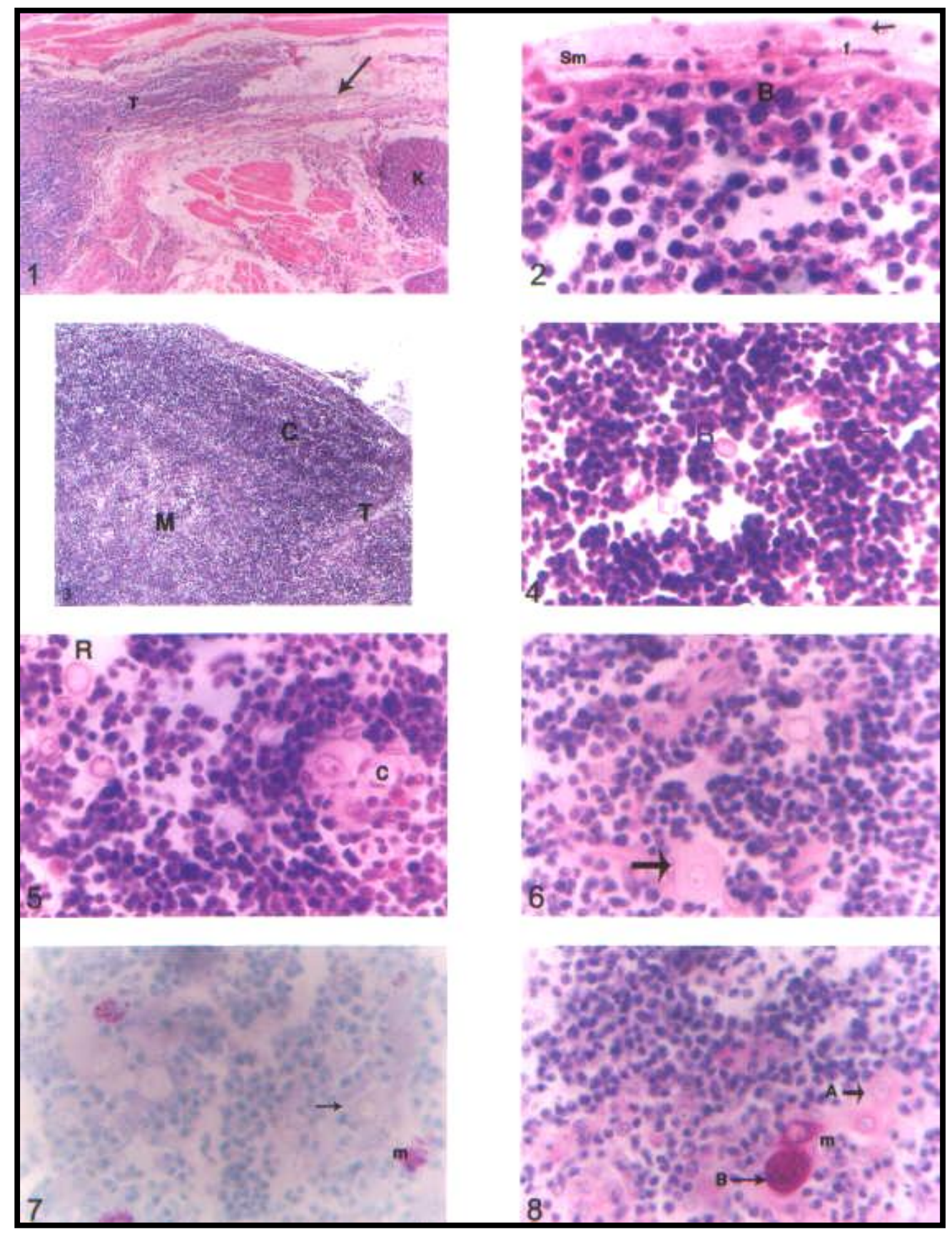

$\overline{\text { Kafrelsheikh Vet. Med. J. Vol. } 6 \text { No. } 1 \text { (2008) }}$ 


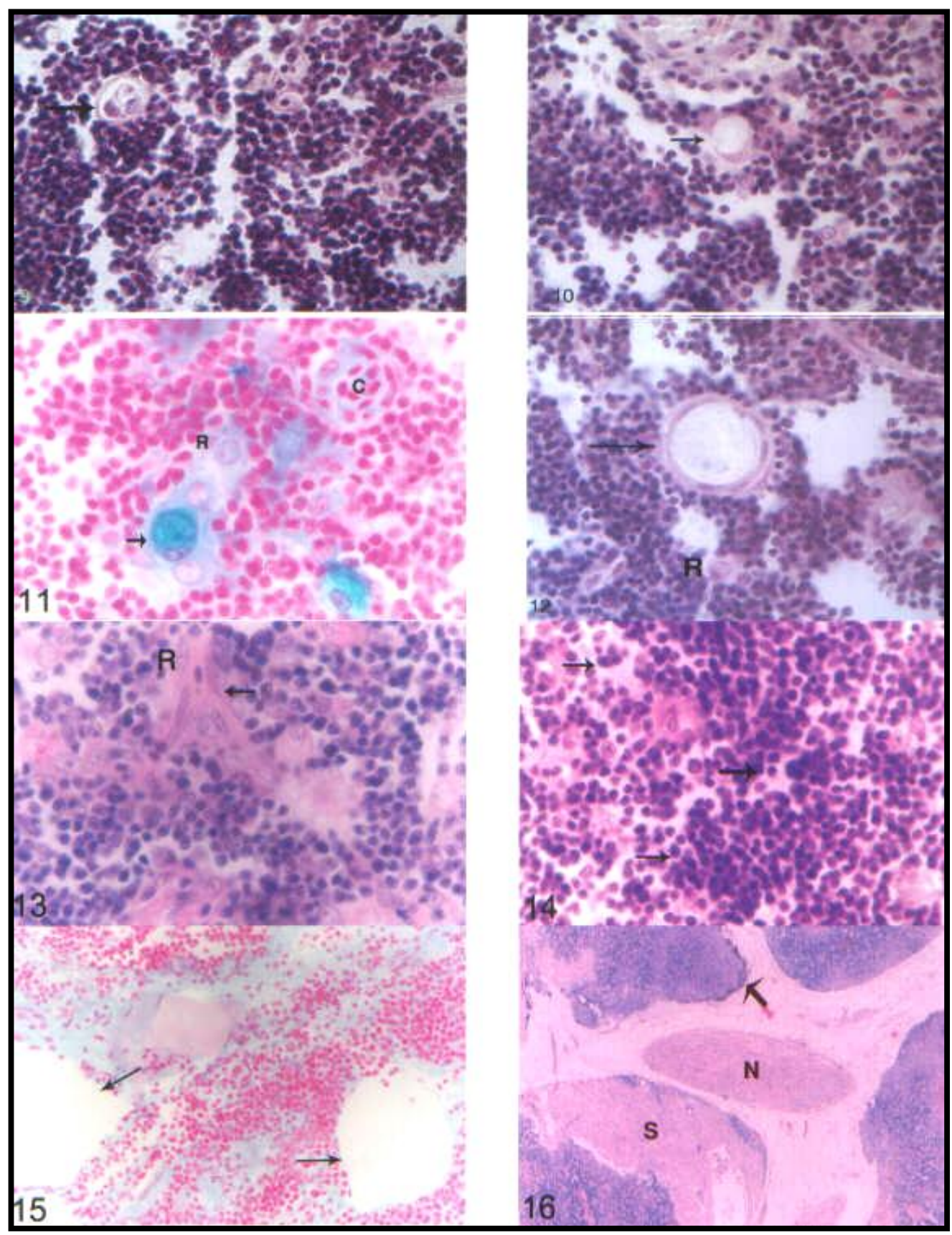

$\overline{\text { Kafrelsheikh Vet. Med. J. Vol. } 6 \text { No. } 1 \text { (2008) }}$ 


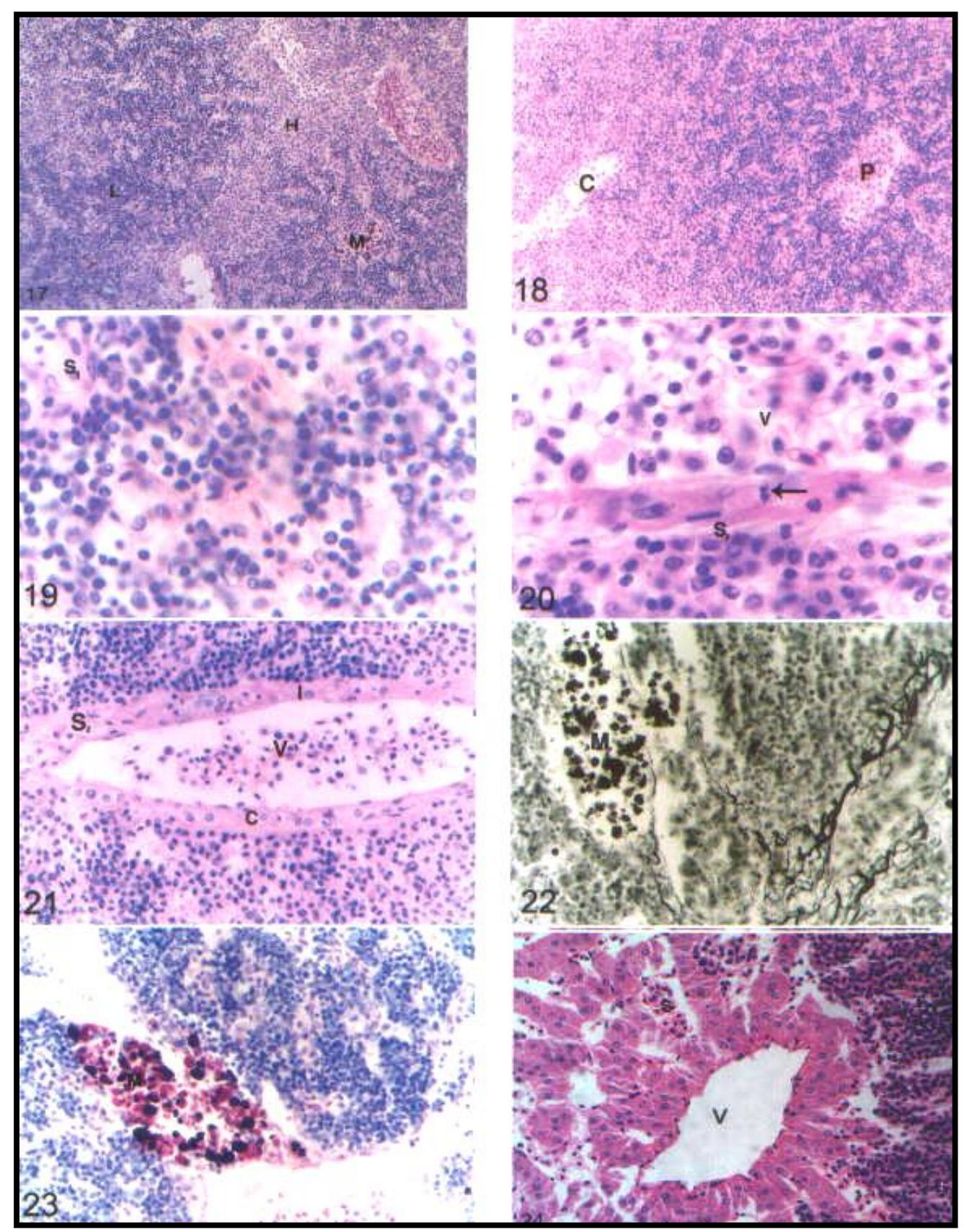

$\overline{\text { Kafrelsheikh Vet. Med. J. Vol. } 6 \text { No. } 1 \text { (2008) }}$ 


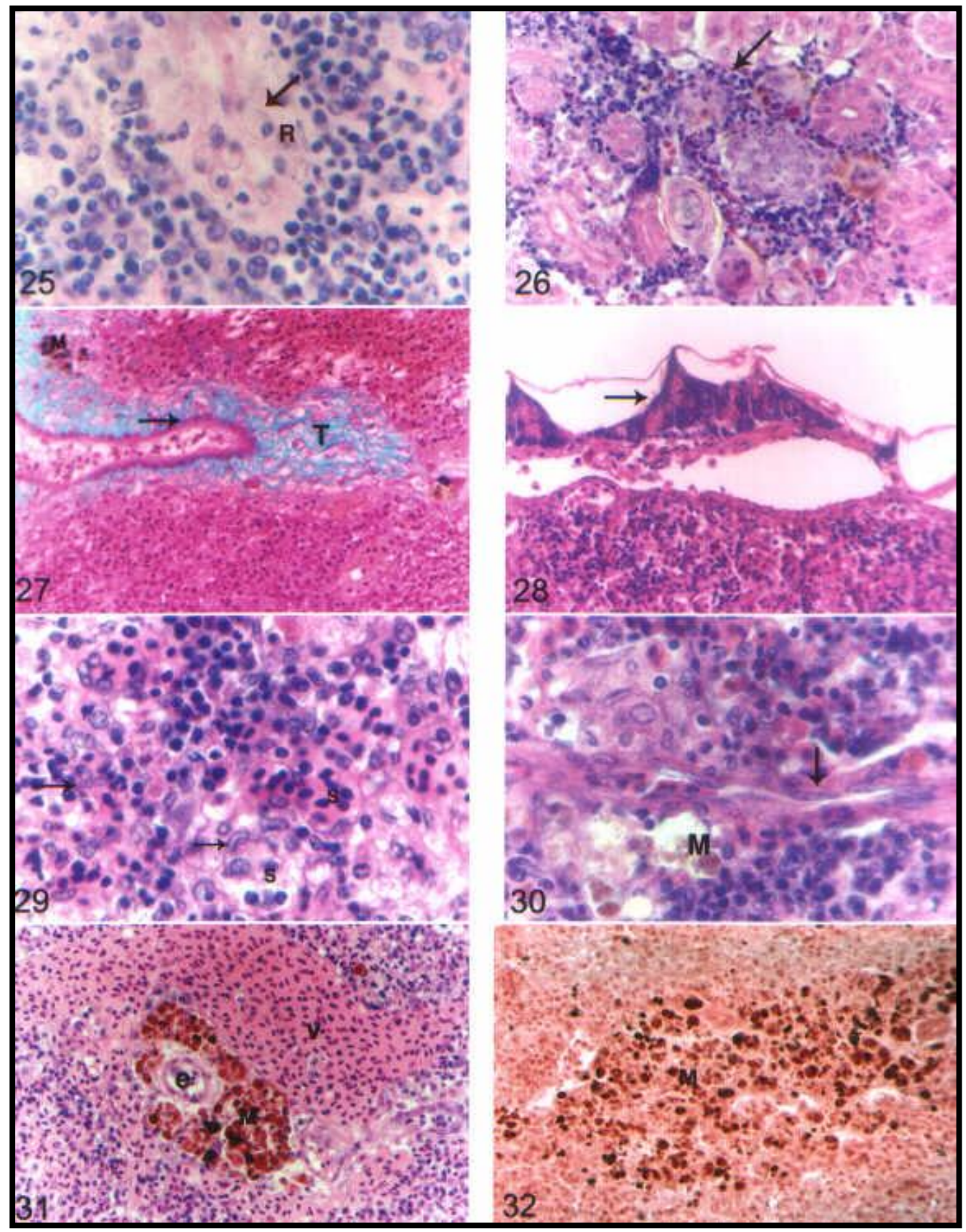

$\overline{\text { Kafrelsheikh Vet. Med. J. Vol. } 6 \text { No. } 1 \text { (2008) }}$ 


\section{REFERENCES}

- Abd-Rabou, M. I. (2002): Histological and histochemical studies on the kidney of the Gilthead seabream fish (Sparus aurata). M. V. Sc. thesis. Faculty of Veterinary Medicine, Cairo University, Egypt.

- Abelli, L.; Baldassini, M. R.; Meschini, R. and Mastrolia, L. (1998): Apoptosis of thymocytes in developing sea bass Dicentrarchus labrax. Fish Shellfish Immunol., 8: 13-24

- Agius, C. (1979): Aspects of the melano-macrophage centres in fish.ph.D. Thesis, University of Stirling.

- Agius, C. (1980): Phylogenetic development of melanomacrophage centres in fish. J. of Zool., 191: 11-32.

- Agius, C. and Roberts, R. J. (2003): Melano-macrophage centres and their role in fish pathology. J. Fish Dis., 26: 499509.

- Alvarez, F.; Flano, E.; Villena, A.J.; Zapata, A. and Razquin, B.E. (1994): Seasonal intrathymic erythropoitic activity in trout.Dev.Comp. Immunol., 18(5): 409-420.

- 7-Alvarez, F.; Razquin, B. E; Villena, A. J. and Zapata, A. (1998): Seasonal changes in the lymphoid organs of Wild brown Trout, Salmo trutta L: a morphometrical study. Vet. Immunol. Immunopath., 64(3): 267-278.

- Anderson, D. P. and Mitchum, D. L. (1974): Atlas of Trout Histology Textbook, Wyoming game fish department Cheyenne. Wyoming.

- Bagchi, S and Pal, J. (2004): Histological studies of the

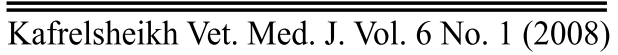


thymus of healthy and epizootic ulcerative syndrome affected fish, Cirrhinus mrigala.Env. and Ecol., 22(3): 555-559.

- Bancroft, J. D. and Stevens, A. (1982): Theory and practice of histological techniques. Second Edition. Churchill Livingstone. Edinburgh. London. Melbourne and New York.

- Beitch, I. (1962): A histomorphological comparison of the urinary system in Serranid fishes Roccus saxatilis and R.americanus. Master's thesis. University of Richmond, Richmond, Virginia, USA.

- Bielek, E. (1981): Developmental stages and localization of peroxidase activity in the leucocytes of three Teleost species (Cyprinus caprio L., Tinca tinca L., Salmo gairdneri). Cell and Tissue Res., 220: 163-180.

- Boehm, T.; Bleul, C. C. and Schorpp, M. (2003): Genetic dissection of thymus development in mouse and zebrafish.Imm. Rev., 195:15-27.

- Bowden, T. J.; Cook, P. and Rombout, J. H. W. M. (2005): Development and function of the thymus in teleosts.Fish and Shellfish Immunol., 19: 413-427.

- Carpenter, S. J. and Hely, H. L. (1974): Fine structure of the corpuscles of Stannius of Atlantic salmon during the freshwater spawning journey.Gen. Comp. Endocrinol., 23: 212223.

- Castillo, A.; Razquin, B. E.; Lopez-Fierro, P.; Alvarez, F.; Zapata, A. and Villena, A. J. (1990): Enzyme- and immuno- 
histochemical study of the thymic stroma in the rainbow trout, Salmo gairdneri, Richardson. Thymus; 15: 153-66.

- Chilmonczyk, S. (1984): The thymus of the rainbow trout Salmo gairdneri. Light and electron microscopy study.Dev. Comp. Immunol., 7: 59-68.

- Cook, H. C. (1974): Manual of histological demonstration techniques. Butterworths and Co. 1td., Lowe and Brydone ltd. London, Thetford Haverhill.

- Crossmon, G. (1937): A modification of mallory's connective tissue stain with a discussion of principles involved. Ibid., 69: 33-38.

- Dalmo,R. A. and Bogwald, J. (1996): Distribution of intravenously and peroraly administrated Aeromonas salmonida lipo-polysaccaride in Atlantic salmon, Salmo salar L. Fish and Shellfish immunol., 6: 427-441.

- Dezfuli, B. S.; Simoni, E.; Rossi, R. and Manera, M. (2000): Rodlet cells and other inflammatory cells of Phoxinus phoxinus infected with Raphidascaris acus (Nematoda).Dis. Aquat. Organ 43: 61-69.

- Diab, A. S.; Marei, H. E. and Smith, S. A. (1995): Effects of dimethoate on ontogeny of the Oreochromis niloticus immune organs; light and electron microscopic study. Zagazig Vet. J., 23: 132-143.

- Drury, R. A. B. and Wallington, E. A. (1980): Carleton's histological technique. Fourth Edition oxford university press, New York, Toronto.

- Ellis, A. E. (1976): Leucocytes and related cells in the plaice 
(pleuronectes platessa). J. of Fish Biol., 8: 143-156.

- Ellis, A. E. (1977): Ontogeny of the immune response in Salmosalar. Histogenesis of the lymphoid organs and appearance of membrane immunoglobulin and mixed leucocyte reactivity. Developmental Immunobiology (Eds. J. B. Solomon and J. D. Horton), pp. 225-231. Elsevier/ North Holland Biomedical press.

- Ellis, A. E.; Munro, A. L. S. and Roberts, R. J. (1976): Defense mechanisms in fish. 1. A study of the phagocytic system and the fate of intraperitoneally injected particulate material in the plaice (Pleuronectes platessa L.) J. Fish Biol., 8: 67-78.

- El-Shammaa, M. A. S. (1987): Studies of the immune system of common carp fish (Caprinus carpio L.). M.V.Sc.thesis.. Faculty of Veterinary Medicine, Cairo University, Egypt.

- Espenes, A.; Press, C. M.; Dannevig, B. H. and Landsverk, T. (1995): Investigation of the structural and functional features of splenic ellipsoids in rainbow trout (Oncorhynchus mykiss). Cell Tissue Res., 279:469-474.

- Fishelson, L. (1996): Ontogenesis and functional metamorphosis of the head kidney in Bottom spawner and Mouth brooder cichild fishes (Cichlidae, Teleostei). J. Morphol., 229: 1-21.

- Fishelson, L. (2006): Cytological and morphological ontogenesis and involution of the thymus in cichlid fishes (Cichlidae teleostei).J. of morph. 223(2):175-190.

- Fournier-Betz, V.; Quentel, C.; Lamour, F. and Le Ven, A. (2000): Immunocytochemical detection of Ig-positive cells in blood, lymphoid organs and the gut associated lymphoid tissue 
of the turbot (Scophthalmus maximus). Fish Shellfish Immunol;10:187-202.

- Freida, L. and Carson, H. T. (1990): Histotechnology: A self instructional text.

- Grizzle, J. M. and Rogers, W. A. (1979): Anatomy and histology of the channel cat fish. Department of Fisheries and Allied Aquaculture 2nd printing.

- Groman, D. B. (1982): Histology of the striped bass. American fisheries Society. Bethesda.

- Grove, S.; Johansen, R.; Reitan, L. J. and Press, C. M. (2006): Immune- and enzyme histochemical characterisation of leucocyte populations within lymphoid and mucosal tissues of Atlantic halibut (Hippoglossus hippoglossus)Fish and Shellfish Immunol., 20: 693-708.

- Herraez, M. P. and Zapata, A. G. (1991): Structural characterization of the melano-macrophage centers (MMC) of goldfish (Carassius auratus).European J. Morphol., 29: 89102.

- Imagawa, T.; Hashimoto, Y.; Kon, Y. And Sugimura, M. (1990): vascularization and related distribution of leucocytes in carp, (Cyprinus carpio L)., kidney. J.of Fish Boil., 37: 357366.

- Lamers, C. H. J. and De Haas, M. J. H. (1985): Antigen localization in the lymphoid organs of carp (Cyprinus carpio). Cell and Tissue Res., 242: 491-498.

- Lin, H. T.; Lin, H. Y. and Yang, H. L. (2005): Histology and Histochemical enzyme-staining patterns of major immune 
organs in Epinephelus malabaricus. J. of Biol., 66: 729-740.

- Liu, Y.;Zhang, S.;Jiang, G.; Yang, D;Lian, J. and Yang, Y. (2004): Development of the lymphoid organs of flounder, Paralichthys olivaceus, from hatching to 13 months.Fish and Shellfish Immunol., 16 (5):621-632.

- López-Ruiz, A.; Esteban, M. A. and Meseguer, J. (1992): Blood cells of the Gilthead seabream (Sparus aurata L.) light and electron microscopic studies. Anat. Rec., 234: 161-171.

- Macchi, G. J.; Romano, L. A. and Christiansen, H. E. (1992): Melanomacrophage centers in white mouth croaker micropogonias of urneri as biological indicator of environmental changes. J. of Fish Biol., 40: 971-973.

- Manera, M. and Dezfuli, B.S. (2004): Rodlet cells in teleosts: A new insight into their nature and functions (Review). J. Fish Biol., 65:597-619.

- Manning, M. J. (1981): A comparative view of the thymus in vertebrates in: The thymus gland (M.D. ikendall. Ed). Academic Press, London, pp. 7-20.

- Marei, H.E.S. (2003): Structure of the spleen of the Nile tilapia (Oreochromis niloticus): Light and electron microscopic studies.Mansoura Vet. Med. J., 1: 133-154.

- Mazon, A. F.; Huising, M. O.; Taverne-Thiele, A. J.; Bastiaans J. and Verburg-van Kemenade, B. M .L. (2007): The first appearance of rodlet cells in carp(Cyprinus carpio L.) ontogeny and their possible roles during stress and parasite infectionFish and Shellfish Immunol., 22: 27-37 
- Meseguer, J.; López-Ruiz, A. and Garcia- Ayala, A. (1995): Reticulo-endothelial stroma of the head kidney from the seawater Teleost and Gilthead sea bream (Sparus aurata L.): An Ultrastructural and Cytochemical study. Anat. Rec., 244: 303-309.

- Ohl, L.; Bernhardt, G.; Pabst, O. and Forster, R. (2003): Chemokines as organizers of primary and secondary lymphoid organs. Sem. Immunol., 15: 249-255.

- Pearse, A.G.E. (1972): Histochemistr,Theoretical and Applied, $3^{\text {rd }}$ ed. Churchill-Livingstone, London.

- Petrie-Hanson L. and Ainsworth (2000): Ontogeny of channel catfish lymphoid organs. Vet. Immunol. Immunopath., 30; 81(1-2): 113-127.:

- Press, C. M. C. L., Dannevig, B. H. and Landsverk, T. (1994): Immune and enzyme histochemical phenotypes of lymphoid and non lymphoid cells within the spleen and head kidney of Atlantic salmon (Salmo salar L).Fish and Shellfish Immunol. 4,79-93.

- Press, C. M. C. L. and Evensen, O. (1999): The morphology of the immune system in Teleost fishes.Fish and Shellfish Immunol., 9: 309-318.

- Reite, O.B. (2005): The rodlet cells of teleostean fish: their potential role in host defence in relation to the role of mast cells/eosinophilic granule cells. Fish and Shellfish Immunol., 19: 253-267.

- Rizkalla, W. (1969): Studies on the thymus of the Nile teleosts 
fish, Clarius lazera C. and V. Acta. Veterinarian Academiae Scientarum hungaricae, Tomus 19 (4) pp. 331-342.

- Roberts, R. J. (1975): Melanin- containing cells of teleost fish and their relation to disease. In "The Pathology of Fishes" (Eds. W. E. Ribelin and G. Migaki), pp. 399-428,Madison, University of Wisconsin press.

- Roberts, R.J. (2001): Fish Pathology, 3rd ed. W.B. Saunders, Philadelphia, PA.

- Romano, N.; Fanelli, M.; Del Papa, M.G.; Scapigliati, G. and Mastrolia, L. (1999):Histological and cytological studies on the developing thymus of sharpsnout seabream, Diplodus puntazzo. J. Anat., 194(Pt 1):39-50.

- Sailendri, k. and Muthukkaruppan V.R. (1975): Morphology of lymphoid organs in cichlid teleost, Tilapia mossambica (peters). J. of morph., 147: 109-122.

- Sameerah, O. A. B. (1991): Developmental studies of the immune system of Tilapia fish (Red tilapia). M.V.Sc.thesis. Giril's College of education in Jeddah.

- Schneider, B. (1983): Ontogeny of fish lymphoid organs. Dev. Comp. Immunol., 7: 739-740.

- Secombes, C.J., Manning, M.J. and Ellis, A.E. (1982): The effect of primary and secondry Immunization on the lymphoid tissue of the carp, (Cyprino Carpio L). J. of Experimental Zool., 220: $277-278$.

- Takashima F. and Hibiya T. (1995): An Atlas of Fish Histology. Normal and pathological features. Kodansha Ltd. 
Gustav Fischer Verlag Stuttgart. New York, 1-56.

- Urasa, F. M. and Wendelaar-Bonga, S. E. (1985): Stannius corpuscles and plasma calcium levels during the reproductive cycle in the cichlid teleost fish (Oreochromis mossambicus). Cell Tissue Res., 241(1): 219-227.

- Wendelaar-Bonga, S. E. and Greven, J. A. (1975): A second cell type in Stannius bodies of two euryhaline teleost species. Cell Tissue Res., Jun 9; 159 (2): 287-290.

- Xu-leren; Yang-Xiaozhen; Gao-Denghui and Jiang-Ping (2003): Mast cells in two species of fresh-water fishes, grass fish (Ctenopharyngodon idella) and catfish (Clarias fuscus lacepede). J. of Animal and Vet. Advances 2 (3): 191-195.

- Yoffey, J.M. (1929): A contribution to the study of the comparative histology and physiology of the spleen, with references chiefly to its cellular constituents.in fishes.J. Anat., 63: 314-344.

- Zapata, A. (1980): Ultrastructure of elasmobranch lymphoid tissue in Thymus and spleen.Dev. Comp. Immunol., 4: 459-472.

- Zapata, A.G.; Torroba, M.; Sacedón, R.; Varas and Vicente, A. (1996): Structure of the lymphoid organs of elasmobranchs.The J. of Exp. Zool., 275: 125-143.

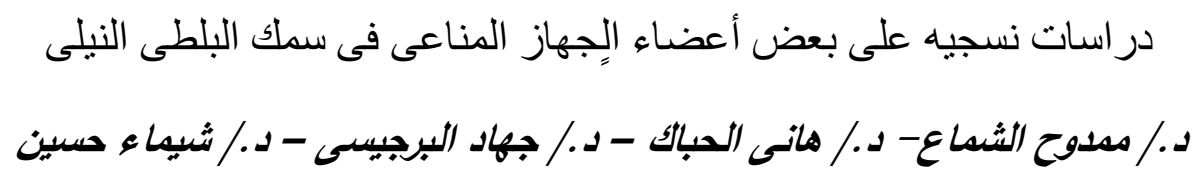




\section{قسم الخلية و الأنسجة-كليه الطب البيطرى - جامعه القاهرة}

أقيمت الدراسة علي الغدة التوتية و الكلية و الطحال لخمسين من أسماك البلطي النيلي. وجد أن الغدة التوتية مغطاة بمحفظة طلائية ترسل فواصل قصيرة كما يتميز النسيج البرنشيمى بوجود قشره ولب. تتكون القشرة من عدد كبير من الخلايا الليمفاويه و قليل من الخلايا الطلائية الثبكية أما اللب فيتكون من قليل من الخلايا التوتية وعدد كبير من الخلايا الطلائية الثبكية تتميز كلي سكك البلطي النيلي إلى الكليه الرأسيه و الكليه الجزعيه اللتان تلتحمان مباشرة. وتغطى الكلية الرأسية بمحفظة رقيقه. ل لا تتميز الكلية الأمامية إلى قثره ولب. يوجد تحت المحفظة نسيج منشئ للام الذى يتكون من مجموعه من الخلايا الحبييية وكرات الدم الحمراء في مراحل النمو والتمايز المختلفة بالإضافة إلي عدد من الخلايا اليمفاوية الموجودة بالقرب من الوعاء الدموى. تتكون الخلايا الدعامية من نوعان من الخلايا. تحيط كريات ستانس بالأوعية الدموية. وتتألف كل كريه من أحبال أو تجمعات بينها جيوب دمويه. أما بالنسبة للكلية الجزعية فيتكون النسيج البينى من النسيج المنشىء للام والنسيج الليمفاوى وكذلك المراكز البالعة الصبغية الغير محاطة بألياف شبكيه, كما لوحظ

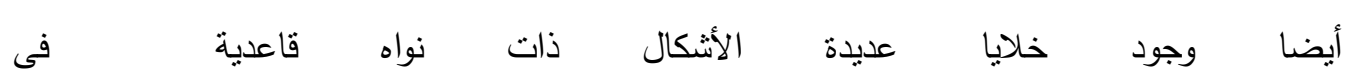
الأنابيب البولية.

يحاط طحال أسماك البلطى النيلى بمحفظة رقيقه وتتكون هذه المحفظة من ألياف غرويه, وألياف شبكيه وعضلات ملساء. كما تحاط المحفظة بخلايا طلائية وسطيه. يتميز الطحال إلى لب أحمر ولب أبيض غير مكتمل وتجمعات من الخلايا البالعة الصبغية. ويحتوى الطحال أيضا على النسيج المنشى للام, كما تم ملاحظة عنبات البنكرياس القنوية تحت المحفظة. 